\title{
ANALISIS PENGARUH VARIASI SUHU dan WAKTU PADA PROSES HIDROLISIS TERHADAP KADAR GLUKOSA DALAM PEMANFAATAN Lemna minor SEBAGAI BIOETANOL
}

\author{
Oleh : \\ Vivi Mayangsari ${ }^{1}$ dan Ahmad Abtokhi ${ }^{2}$
}

\begin{abstract}
ABSTRAK: Energi terbarukan sangatlah diperlukan karena semakin meluasnya krisis energi sehingga memerlukan alternatif selain penggunaan bahan bakar fosil, penggunaan bioethanol merupakan alternatif yang baik karena banyak kelebihanya. Lemna minor merupakan salah satu tumbuhan yang berpotensi sebagai bioethanol, hal ini dapat dilihat dari kandungan glukosanya yang tinggi. Tujuan penelitian ini adalah untuk mengetahui hubungan waktu dan suhu pada proses hidrolisis terhadap nilai kadar glukosa serta mengetahui hubungan densitas terhadap kadar etanol. Proses ekstrasi glukosa menggunakan perbandingan volume $\mathrm{HCl}$ dengan kosentrasi $0,1 \mathrm{~N}$, berat serbuk Lemna minor dan volume aquades yaitu 1:10:100 dengan variasi waktu ekstrasi 60, 90, dan 120 menit pada variasi suhu $60,70,80^{\circ} \mathrm{C}$ dengan ukuran serbuk 60 mesh. Hasil penelitian ekstrasi hidrolisis terbaik pada menit ke-90 didapatkan panjang gelombang tertinggi $415 \mathrm{~nm}$. Semua glukosa pada ekstrasi 90 menit difermentasi menggunakan bakteri Saccharomiches cerevisiae sebanyak 10\% dari volume glukosa dengan waktu 144 jam, setelah fermentasi selesai sampel didestilasi untuk menghilangkan kadar air dan dihasilkan kadar ethanol terbaik $0,47 \%$ dengan densitas $0,9345 \mathrm{gr} / \mathrm{ml}^{3}$ pada panjang gelombang larutan glukosa $316 \mathrm{~nm}$.
\end{abstract}

Kata kunci: Suhu, waktu, hidrolisis, glukosa, Lemna minor, bioetanol

\begin{abstract}
Rewenable energi is absolutely necessary because increasingly the wide spread of energy crisis so is requiring an alternative energy besides use of fossil fuels, the employing of bioethanol is good alternative because have many exess. Lemna minor is one of the plants wich potentially as a bioetanol, it can be seen from a high glucose content. The aim of this reseaerch is to find the relation of temperatur and time on proces hydrolysis against glucose and to find relation density to ethanol levels. The extraction proces of glucose using volume comparison $\mathrm{HCl}$ with concentration 0,1 N,Lemna minor powder weight and volume of aquades is 1:10:100 with variations of extraction time $60,90,120$ minute at temperature variations $60,70,80{ }^{\circ} \mathrm{C}$ with the size of the powder 60 mesh. The best result of hidrolysis extration in 90 minute can be obtained the highest value of wavelength is $415 \mathrm{~nm}$. All the glucose at the extraction in 90 minute was fermented using bacteria Saccharomiches cerevisiae $10 \%$ of the volume of glucose with the time 144 hours. After fermentation was completed the sampel was destileted to removing the water level and generate the best ethanol level $0,47 \%$ with density $0,9345 \mathrm{gr} / \mathrm{ml}^{3}$ at wavelength glucose solution is $316 \mathrm{~nm}$.
\end{abstract}

Keyword: temperature, time, hidrolysis, glucose, Lemna minor, bioethanol

1 Mahasiswa Jurusan Fisika, Fakultas Sains dan Teknologi, UIN Maliki Malang (email:ningvivi3@gmail.com)

${ }^{2}$ Staf Pengajar pada Jurusan Fisika, Fakultas Sains dan Teknologi UIN Maliki Malang (email:abtokhi76@yahoo.co.id) 


\section{PENDAHULUAN}

Cadangan bahan bakar di bumi sangat terbatas dan semakin habis karena konsumsi masyarakat tiap tahun meningkat sehingga mengakibatkan adanya krisis energi, untuk menghindari krisis energi tersebut perlu adanya energi terbarukan yaitu bahan bakar pengganti dari bahan bakar fosil. Bioetanol merupakan salah satu sumber energi alternatif yang mempunyai beberapa kelebihan, diantaranya sifat etanol yang dapat diperbarui dan ramah lingkungan karena emisi karbondioksidanya rendah [2]. Etanol dapat digunakan sebagai bahan campuran bensin (gasolin) yang kemudian dinamakan gasohol, dan juga dapat digunakan secara langsung sebagai bahan bakar [4].

Salah satu alternatif untuk membuat bioetanol dapat digunakan tanaman Duckweed (Lemna minor). Duckweed merupakan jenis tanaman yang banyak ditemui di sawah maupun di pinggir-pinggir tambak, terkadang juga bisa menutupi keseluruhan permukan air. Tumbuhan ini menyebabkan kadar oksigen dalam air berkurang, hal ini menjadikan mahluk hidup dalam air akan mati, Duckweed mengandung karbohidrat sebesar 40\%$50 \%$, abu $24 \%$ dan energi $3 \%$. Sehingga tanaman ini layak untuk dijadikan bioetanol dari segi kandunganya dan ketersedianya di Indonesia [3].

Jenis penelitian ini adalah penelitian eksperimental yang bertujuan untuk menganalis pengaruh variasi waktu dan masa pada proses hidrolisis dalam pemanfaatan Lemma minor sebagai bioetanol serta mengetahui hubungan densitas terhadap kadar etanol, ekstrasi glukoa meggunakan katalis $\mathrm{HCl} 0,1 \mathrm{~N}$ dengan pelarut aquades.

Lemna minor yang didapatkan dibersihkan dengan air dan dipisahkan dengan pengotornya, kemudian dikeringkan dibawah sinar matahari selama 4 hari untuk menghilangkan kadar air didalam Lemna minor, Lemna minor yang telah kering kemudian dihaluskan dan diayak dengan ukuran 60 mesh agar mempermudah ekstrasi glukosa dalam proses hidrolisis. Proses ektrasi perbandingan volume aqades, bert sampel dan volume katalis 100:10:1 [1]. Proses hidrolisis ini diawali dengan menimbang serbuk Lemna minor seberat 50 gram kemudian diberi larutan aquades dengan HCL dengan perbandingan 10 : 1. Lemna minor dan aquades dimasukan ke dalam tabung reaksi $1000 \mathrm{~mL}$ dan dipanaskan pada hot plate dan diaduk dengan kecepatan $800 \mathrm{rpm}$ pada variasi suhu $60^{\circ} \mathrm{C}, 70^{\circ} \mathrm{C}, 80^{\circ}$ $\mathrm{C}$ dengan variasi waktu selama 60 menit, 90 menit dan 120 menit, Setelah proses hidrolisis selesai, sampel kemudian disaring menggunakan kain saring untuk memisahkan cairan dengan padatan hasil ekstrasi, cairan hasil ekstrasi glukosa yang di dapat kemudian diuji kadar glukosanya menggnakan UV-Vis dan hasil padatanya bisa dimanfaatkan sebagai pakan ternak.

Bakteri yang digunakan dalam proses fermentasi adalah bakteri Saccharomycess serevisiae, tujuan penggunaan bakteri Saccharomycess serevisiae karena bakteri ini dapat memproduksi alkohol dalam jumlah besar dari glukosa, namun toleransinya sangat rendah terhadap garam sehingga membutukan tempat penyimpanan yang steril. Pembuatan starter menggunakan aquades $1000 \mathrm{~mL}$ dengan gula pasir 100 gram kemudian dimasukan kedalam beaker glass lalu diaduk pada hot plate dengan kecepatan 350 rpm pada suhu 200 ${ }^{\circ} \mathrm{C}$, kemudian disterilisasi menggunakan autoclave pada suhu $121{ }^{0} \mathrm{C}$ selama 15 menit. Substat kemudian didinginkan sehingga suhunya mencapi $27-30{ }^{\circ} \mathrm{C}$, setelah dingin 
diambil bakteri satu oshe menggunakan jarum inakulasi lalu dimasukan kedalam substrat setelah itu di inkubasi selama 24 jam pada suhu $33^{\circ} \mathrm{C}$.

Proses fermentasi menggunakan $\mathrm{pH}$ 4,5, hal ini diperlukan agar bakteri dapat mengubah glukosa dari Lemna minor menjadi alkohol dengan baik. Proses fermentasi dilakukan dalam kondisi anaorobik dengan penambahan stater $10 \%$ dari volume glukosa selama 144 jam. Destilasi dilakukan dengan tujuan memisahkan campuran-campuran dari alkohol hasil dari fermentasi, destilasi dilakukan pada rentang suhu $80-100^{\circ} \mathrm{C}$ sehingga etanol yang dihasikan tidak banyak menguap. Hasil dari destilasi diukur densitasnya menggunakan picknometer sedangkan nilai etanolnya diuji dengan GC.

\section{HASIL DAN PEMBAHASAN}

\section{A. Hasil Pengujian UV-Vis Pada Larutan Glukosa}

1. Pengaruh Suhu Terhadap Panjang Gelombang Glukosa

Proses ekstrasi glukosa, temperatur harus dijaga tetap konstan karena hal ini berpengaruh pada laju reaksi larutan, jika suhunya tidak konstan maka laju yang diamati berbeda-beda sehingga mempengaruhi hasil akhir dari penelitian.

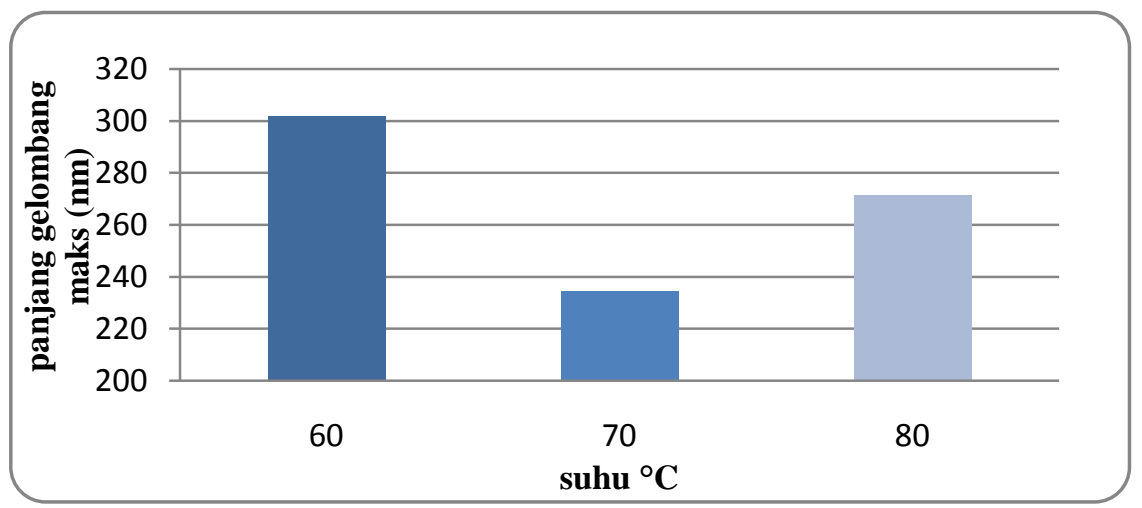

Gambar 1. Grafik pengaruh suhu terhadap nilai panjang gelombang maksimum larutan gukosa pada waktu ekstrasi 60 menit

Gambar 1 menunjukan bahwa niai gelombang maksimal tertinggi terdapat pada suhu $60{ }^{\circ} \mathrm{C}$ dengan waktu ekstraksi 60 menit sehingga dapat dilihat bahwa tumbukan yang terjadi pada suhu $60^{\circ} \mathrm{C}$ sangatlah besar sehingga pemebentukan dari amilum dengan katalis $\mathrm{HCl}$ 0,1 $\mathrm{N}$ dicampur dengan air menghasilkan ikatan glukosa paling tinggi.

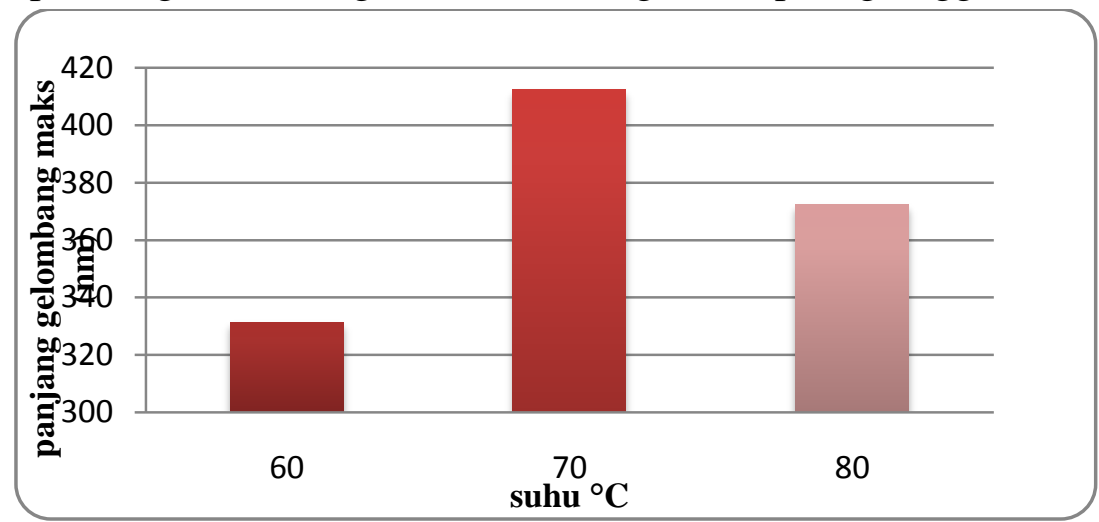

Gambar 2. Grafik pengaruh suhu terhadap nilai panjang gelombang maksimum larutan gukosa pada waktu ekstrasi 90 menit 
Gambar 2 menunjukan semakin besar suhu yang diberikan dengan waktu ekstrasi 90 menit hampir semua pereaksi menjadi lebih cepat bila suhu dinaikkan dengan waktu 90 menit, karena kalor yang diberikan akan menambah energi kinetik partikel pereaksi, Akibatnya, jumlah dan energi tabrakan bertambah besar. Frekuensi tumbukan meningkat dengan meningkatnya suhu. Namun jika suhu terlalu tinggi diatas $70{ }^{\circ} \mathrm{C}$, maka katalis $(\mathrm{HCl})$ akan menguap yang mengakibatkan melambatnya reaksi hidrolisis tersebut yang juga akan mempengaruhui pada konsentrasi glukosa yang diperoleh. Glukosa yang terbentuk pada proses hidrolisis pada suhu $70{ }^{\circ} \mathrm{C}$ akan menurun dengan bertambahnya suhu, hal ini dikarenakan semakin tingginya waktu ekstraksi mengakibatkan nilai glukosa akan terdegrasi dan akan larut dengan air.

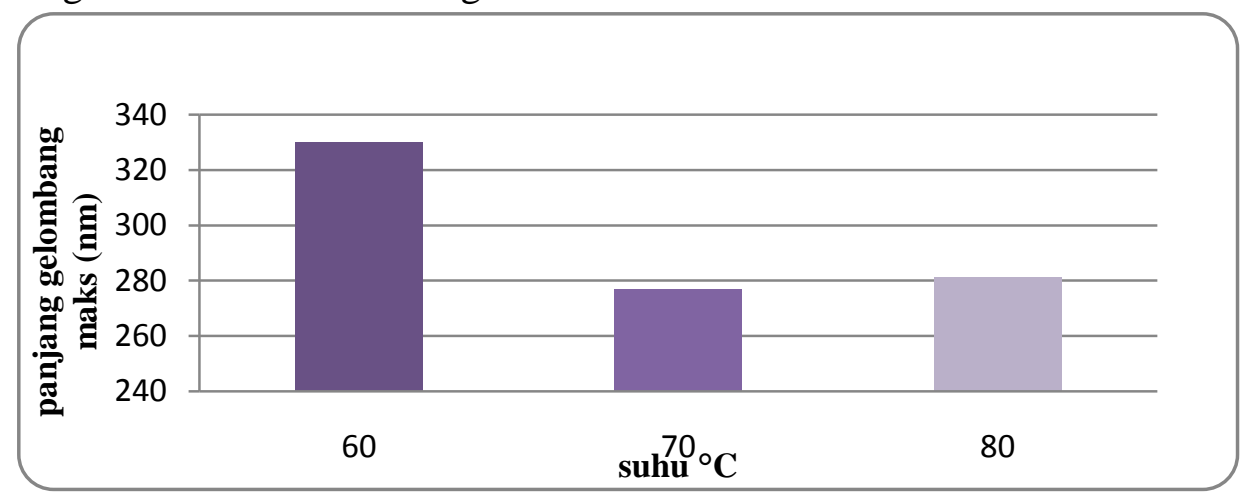

Gambar 3. Grafik pengaruh suhu terhadap nilai panjang gelombang maksimum larutan gukosa pada waktu ekstrasi 120 menit

Dapat dilihat pada gambar 3 menunjukan bahwa semakin naik suhunya maka nilai dari glukosa semakin menurun dan konstan karena tumbukan antar partikel-partikel partisi bisa berubah pada suhu yang tinggi dengan waktu yang lama maka terdapat suhu yang dapat mencapai kesetimbangan termal. Suhu kesetimbangan termal ini tidak dapat merubah suatu reaksi sehingga reaksi larutan itu akan tetap dan tidak dipengaruhi oleh suhu tersebut maka energi dalam larutan tersebut tetap sama. Hal ini berpengaruh terhadap pemecahan karbohidat dalam Lemna minor, jika suhunya tidak mempengaruhi suatu pemecahan karbohidrat menjadi glukosa maka tidak ada reaksi pembentukan glukosa.

\section{Pengaruh Waktu Terhadap Panjang Gelombang Maksimum Glukosa}

Waktu sangat mempengaruhi dari laju reaksi pada pembentukan ikatan glukosa dari pati Lemna minor.

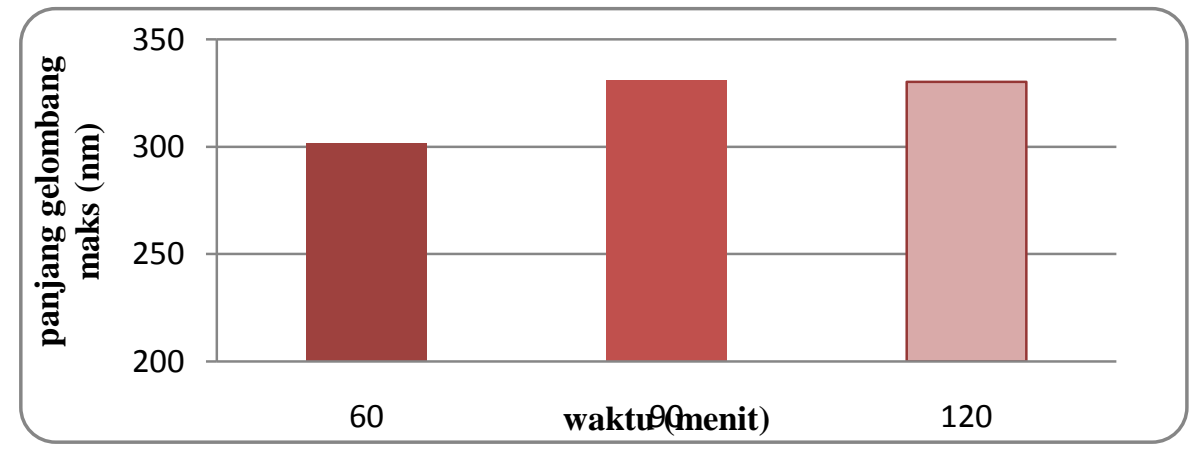

Gambar 4. Grafik hubungan waktu terhadap nilai panjang gelombang maksimum dengan suhu ekstrasi $60^{\circ} \mathrm{C}$ 
Dapat dilihat pada gambar 4 dimana pada proses ektraksi glukosa mempunyai nilai panjang gelombang maksmimum tertinggi menggunakan suhu $60{ }^{\circ} \mathrm{C}$ waktu terbaik adalah 90 menit, setelah ekstrasi selama 90 menit maka nilai dari panjang gelombang maksimum akan tetap konstan. Hal ini dapat dijelaskan dengan laju kesetimbangan pereaksi dimana terdapat reaksi kesetimbangan yaitu keadaan dimana suatu larutan akan setimbang dengan nilai kadar glukosa yang tertinggi, dengan bertambahnya waktu proses akan menjadikan larutan tersebut kualitasnya akan semakin menurun.

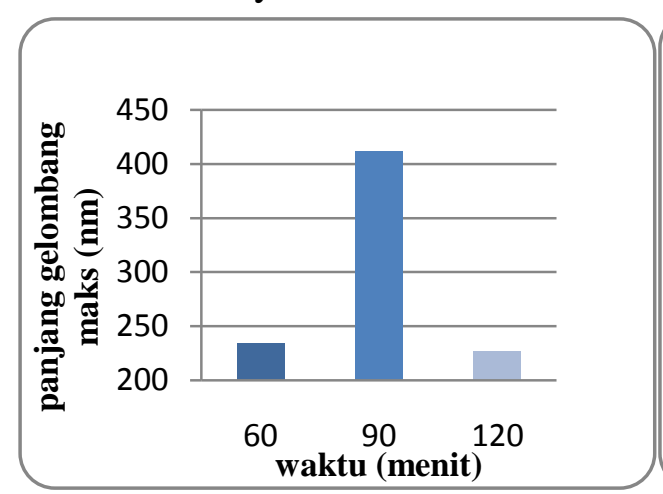

(a)

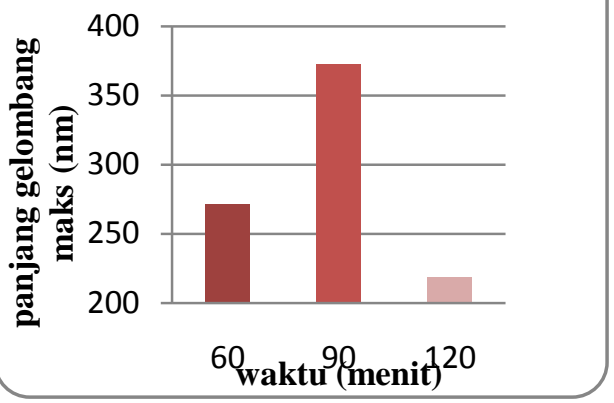

(b)

Gambar 5. Grafik hubungan waktu terhadap nilai panjang gelombang maksimum (a) suhu $70{ }^{\circ} \mathrm{C}(\mathrm{b})$ suhu $80^{\circ} \mathrm{C}$

Gambar 5 menunjukan bahwa waktu terbaik pada proses hidrolisis pada suhu $70{ }^{\circ} \mathrm{C}$ dan suhu $80^{\circ} \mathrm{C}$ adalah menit ke-90, jika waktu semakin tinggi pada proses ekstrasi glukosa mengakibatkan terdegradasinya kadar glukosa sehingga nilai dari kualitas glukosa akan menurun dengan bertambahnya waktu di atas 90 menit.

\section{B. Pengujian Kadar Etanol Menggunakan GC}

Gambar 6 menunjukan hubungan kadar glukosa dengan kadar ethanol dengan menggunakan pengukuran gas kamotografi pada proses ekstrsi selama 90 menit dengan suhu $60{ }^{\circ} \mathrm{C}, 70{ }^{\circ} \mathrm{C}, 80^{\circ} \mathrm{C}$.

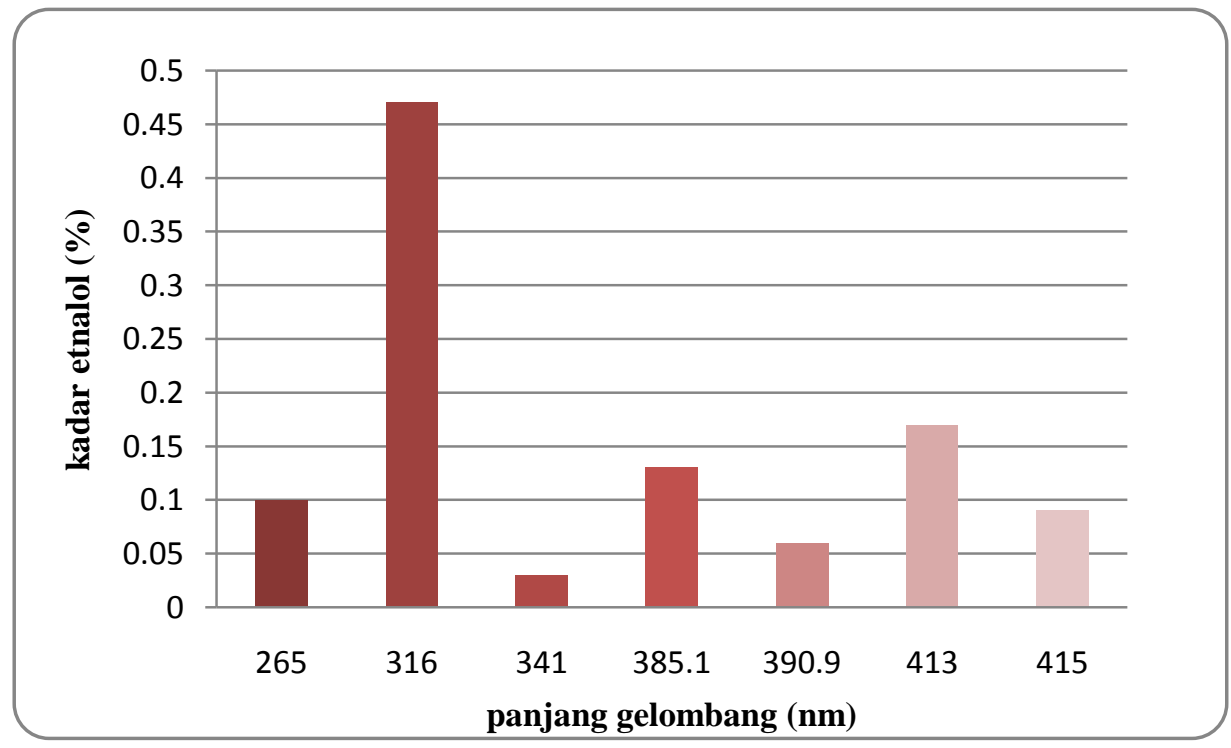

Gambar 6. Grafik hubungan kadar glukosa terhadap kadar ethanol 
Grafik 6 menunjukan bahwa pada panjang gelombang $316 \mathrm{~nm}$ nilai kadar ethanol paling optimum dihasilkan nilai kandugan $0,47 \%$ diikuti dengan nilai panjang gelombang $413 \mathrm{~nm}$, pada panjang gelombang tersebut bakteri membelah secara cepat dan dapat menguraikan glukosa dengan baik. Dapat diketahui bahwa nilai kandungan glukosa sangat berpengaruh dengan kadar ethanol yang dihasilkan, pada panjang gelombang 390,9 $\mathrm{nm}$ nilai kadar etanolnya rendah hal ini bisa disebabkan karena bakteri tidak berkembang biak karena proses fermentasi yang dilakukan tidak berhasil, namun jika substrat yang digunakan melebihi batas ketentuan nutrisi bakteri bisa jadi bakteri dalam substrat tidak membelah secara optimal karena tidak menguraikan seluruh glukosa yang digunakan menjadi etanol.

\section{Pengujian Sifat Fisis Bioetanol}

Densitas yang dihasilkan dari larutan proses fermentasi sangat berhubungan erat dengan nilai kadar etanolnya, nilai densitasnya semakin rendah maka nilai kadar ethanolnya semakin tinggi, hal ini disebakan karena pada suhu tertentu etanol yanng dihasilkan pada proses fermentasi akan mengalami penguapan karena terbawa oleh gas $\mathrm{CO}_{2}$, densitas dari larutan tinggi maka mengakibatkan larutan tersebut akan semakin sulit untuk menguap. Bahan bakar yang paling bagus digunakan adalah bahan bakar yang mempunyai nilai densitas yang semakin rendah dengan bilangan okta yang tinggi. Pengujian densitas menggunakan picknometer dan dihitung dengan rumus

$$
\mathrm{r}=\mathrm{m} / \mathrm{Vp}
$$

dimana:

$$
\begin{aligned}
& \mathrm{m}=\text { massa }(\text { piknometer }+ \text { sampel })-\text { massa piknometer kosong } \\
& \mathrm{Vp}=\text { Volume piknometer }(60 \mathrm{ml})
\end{aligned}
$$

Tabel 1. Hubungan nilai glukosa dengan densitas dan kadar etanol

\begin{tabular}{ccc}
\hline $\begin{array}{c}\text { Panjang } \\
\text { gelombang } \\
\text { glukosa }(\mathrm{nm})\end{array}$ & $\begin{array}{c}\text { Densitas } \\
(\mathrm{gr} / \mathrm{ml} 3)\end{array}$ & $\begin{array}{c}\text { Kadar etanol } \\
(\%)\end{array}$ \\
\hline 316 & 0,9345 & 0,47 \\
385,1 & 0,9373 & 0,13 \\
415 & 0,9385 & 0,09 \\
341 & 0,9446 & 0,03 \\
413 & 0,9455 & 0,17 \\
265 & 0,9465 & 0,1 \\
390,9 & 0,9745 & 0,06 \\
\hline
\end{tabular}

Nilai densitas berhubungan dengan penguapan, jika suhu penguapan semakin besar maka penggunaan bahan bakar semakin hemat, sisa buang rendah, kadar emisi rendah dan asap minimum, menaikan daya minimum tinggi sehingga pembakaran dalam mesin mudah terpecah karena molekul karbon lebih cepat terurai sehingga tidak ada jelaga yang 
dihasilkan, proses untuk mendapatkan kadar etanol tinggi harus melakukan beberapa kali destilasi agar ethanol yang dihasilkan semakin murni (kadar air rendah).

Semakin rendah kadar emisi maka menghasilkan kadar endapan residu yang rendah dalam mesin. Perbandingan pembakaran ethanol dengan besin dapat dilihat bahwasanya pembakaran $1 \mathrm{~kg}$ minyak bumi menghasilkan 10.000 Kkal sedangkam $1 \mathrm{~kg}$ ethanol menghasilkan $12.000 \mathrm{Kkal}$ sehingga lebih efektif pembakaran dalam mesin menggunakan ethanol [5].

Pada densitas lebih dari $0,96 \mathrm{gr} / \mathrm{ml}^{3}$ nilai ethanonya $0,03 \%$ hal ini diketahui bahwa $0,96 \mathrm{gr} / \mathrm{ml}^{3}$ mendekati niali densitas air yaitu $1 \mathrm{gr} / \mathrm{ml}^{3}$, niali dari densitas ethanol sekitar $0,7-0,95 \mathrm{gr} / \mathrm{ml}^{3}$ dan nilai kadar ethanol yang tinggi $0,47 \%$ terdapat pada densitas 0,93 $\mathrm{gr} / \mathrm{ml}^{3}$.

\section{KESIMPULAN}

1. Pada proses Hidrolisis untuk perbandingan terbaik dari volume $\mathrm{HCl} 0,1 \mathrm{~N}$, berat serbuk Lemna minor dan Volume aquades yaitu 1:10:100. Proses ekstraksi glukosa paling optimum pada waktu 90 menit dengan menggunakan suhu diatas suhu ruang

2. Lemna minor berpotensi sebagai bioethanol karena mempunyai kandungan glukosa yang sangat tinggi pada pengenceran $10^{-1}$ pada panjang gelombang maksimum $415 \mathrm{~nm}$

3. Fermentasi glukosa dengan kandungan ( $K$ maks) $316 \mathrm{~nm}$ menggunakan bakteri Saccharomycess sereviae $10 \%$ dari volume glukosa dengan waktu fermentasi 144 jam terdapat kandungan ethanol tertinggi $0,47 \%$. Nilai kandungan ethanol tertinggi $0,47 \%$ terdapat pada absorbansi larutan $266 \mathrm{~nm}$

\section{DAFTAR PUSTAKA}

[1] Jatmiko, dkk. 2011. Pengaruh Suhu Hidrolosa Yang Terbentuk Dan Kecepatan Konstata Kecepatan Reaksi Hidrolosa Kulit Pisang. Yogyakarta: Balai Pengembangan dan Penelitian Kabupaten Pati.

[2] Jeon. 2007. Bioetanol. New England: Livestock Research

[3] Leng, R.A., Stambolie, J.H. and Bell, R. 1995. Duckweed a potential high protein feed resource for domestic animals and fish. New England: Livestock Research for Rural Development, Vol. 7, no. 1.

[4] McKetta, John J, and William Aaron Cunningham. 1983. Encyclopedia of Chemical Processing and Design. New York and Bessel: Marcel Dekker, Inc.

[5] Koesmadinata. 1980. Fisika Energi. Jakarta: Erlangga. 